Ethiopian Journal of Environmental Studies \& Management 9 (2): 137 - 147, 2016.

ISSN:1998-0507

Submitted: September 16, 2015

doi: http://dx.doi.org/10.4314/ejesm.v9i2.2

Accepted: February 15, 2016

\title{
SOIL SUITABILITY EVALUATION FOR RAIN-FED MAIZE PRODUCTION AT GABARI DISTRICT ZARIA KADUNA STATE, NIGERIA
}

\author{
*JIMOH, A.I., 1 YUSUF, Y.O. ${ }^{2}$ AND YAU, S.L. ${ }^{3}$ \\ ${ }^{1}$ Department of Geography, Gombe State University, P.M.B 127, Gombe, Nigeria \\ ${ }^{2}$ Department of Geography, Ahmadu Bello University, P.M.B. 1044, Zaria, Nigeria \\ ${ }^{3}$ Kano State College of Arts, Science and Remedial Studies. P.M.B. 3145, Kano, Nigeria
}

\begin{abstract}
The need to generate adequate information for optimal and sustainable exploitation of the soils of Gabari District Zaria is imperative. The FAO land suitability evaluation was used to evaluate the soils for rain-fed maize cultivation. The total land area surveyed was 70 ha. Three soil units was mapped and designated as GBI 12.3 ha, GBII 38.8 ha and GBIII 18.9 ha. Generally, the surface texture was loam. The soil reactions were slightly acidic to neutral, organic carbon, available phosphorus and total nitrogen was rated low. The CEC $\left(\mathrm{NH}_{4} \mathrm{OAC}\right)$ were medium to high and Base saturation was rated medium while EC and ESP were low. Generally, there were no significant differences in the physical and chemical properties within the three mapping units. Soil mapping units GBI and GBIII were marginally suitable (S3) while GBII was currently not suitable (N1) for maize production due to limitation imposed by soil chemical properties and slope. With proper soil fertility management, the potentials of these soils can be increased to moderately suitable (S2) for rain-fed maize and other arable crops if recommended fertilization and uses of organic manure to improve the soils physical and chemical constraints as well as construction of contour ploughing in unit GBll to reduce the rate of erosion.
\end{abstract}

Key Words: Soil, Suitability Evaluation, Agricultural potential, Gabari District

\section{Introduction}

The role of agriculture in Nigeria's economy cannot be overemphasized given that $70 \%$ of the population derives their means of livelihood; it is also a major source of raw materials for the agro-allied industries as well as a potential source of the much-needed foreign exchange (World Bank, 1998). Agricultural resources are considered to be one of the most important renewable and dynamic natural resources. Soils as basic portions of agricultural resources are the ultimate sources of wealth and the foundation on which civilization is constructed, but a major problem of these resource is inappropriate utilization which leads to inefficient exploitation of the resource, and if proper measure are not put in place could lead to destruction of land resources and finally destruction of civilization (Jafarzadeh and Abbasi, 2006).

To ensure sustainable land management, land degradation has to be checked, through techniques that are cost effective for predicting the best future use, and for mapping and monitoring land use changes. Land evaluation is an applied

*Corresponding Author: Jimoh, A.I.

Email: barhamainyass2k7@yahoo.com 
classification system that assesses the capacity of the soil for its optimal use that is, to derive maximum benefits with minimum degradation. Van Diepen et al. (1991) defined land evaluation as any method which explain or predict the use potential of land. Land evaluation may include soil survey or soil survey data (Abdulkadir, 1986). This help to bridge the gap between soil survey and land use planning by comparing the land conditions and land use requirements. This evaluation of land is normally carried out to determine their suitability for specific uses. The information obtained can now be used for a more realistic land use recommendation and present their constraints (FAO, 1995; Abdulkadir, 1998). A significant and positive response from agricultural is justified as a means of improving the overall performance of the economy.

Maize (Zea mays L.) is the most important cereal crop in sub-Saharan Africa (SSA). Along with rice and wheat, maize is one of the three most important cereal crops in the world. In Nigeria, maize is a staple food of great socio-economic importance. The demand for maize sometimes outstrips supply as a result of the various domestic uses (Akande, 1994). Additionally, other factors like price fluctuation, diseases and pests, poor storage facilities have been associated with low maize production in the country (Ojo, 2003). In view of this, national and international bodies have developed interest in promoting maize production for households' food security and poverty alleviation. Some of these efforts have been channeled through biological and agronomic research into the development of high-yielding varieties along with best cultural practices (Badmus and Ariyo, 2011).
Previous studies on soil suitability include; Oluwatosin (2005) who assessed suitability of some land in Northwestern Nigeria for rainfed crop production using a qualitative physical land evaluation method. The study revealed that all the soils were currently not suitable (N1) for cereals but were marginally suitable (S3) for grain legumes. Soils on plains were potentially more suitable than the soil of the upland and valley bottom. The major limitations were soil fertility, erosion hazard and drainage. Furthermore, Hussaini (2011) evaluate suitability of Institute for Agricultural Research (IAR) farm, Zaria for some selected crops. Three soil mapping units were delineated, two of the soil units were moderately suitable (S2) for cotton and maize but highly suitable for sorghum while the third soil unit was marginally suitable (S3) for cowpea and not suitable (N1) for cotton and maize. Constrain to agricultural productivity in the farm were soil fertility and drainage. Finally, Njar et al. (2012) assessed the suitability of two prominent land parcel for maize production in Obiaruku community of Delta state and found out that the welldrained soil was classified highly suitable (S1) whereas the soil of the riverine area were moderately suitable (S2) for maize production. However, good soil conservation practice is suggested to achieve long term sustainable production of maize in the area.

However, despite the importance of land evaluation on the sustainable management of land and for enhanced crop production, specific soil suitability studies such as suitability assessment for maize production have not been properly documented. This study attempts to contribute to existing knowledge as well as fill the locational gap in knowledge on soil suitability assessment in Zaria. The 
objective of this study is to assess the suitability of Gabari District Zaria for rainfed maize production using the FAO framework for land suitability evaluation FAO (1976).

\section{Materials and Methods}

\section{Description of the study area}

The study site is Gabari District of Sabo Gari Local Government Area of Kaduna State, $\left(11^{\circ} 06^{\prime} 50^{\prime \prime} \mathrm{N}-7^{\circ} 40^{\prime} 22^{\prime \prime} \mathrm{E}\right)$ characterize by Northern Guinea Savanna vegetation type. The area is intensively cultivated to array of crops such as maize, rice, cowpea, onion and tomato. The length of growing period is $150-180$ days
(Yakubu, 2004). Zaria lies within a region which has a tropical Savanna (Aw) climate type with distinct wet and dry season (Kowal and Knabe, 1972). It is characterized by long dry season from November through March while the wet season last for April to October with a mean annual rainfall $1100 \mathrm{~mm}$. The temperature fluctuates within a range from $22^{\circ} \mathrm{C}$ during cold nights to over $38^{\circ} \mathrm{C}$ during the hot days. The relative humidity during dry season is about $15 \%$ and reaches up to $60 \%$ during the rainy season (Kowal and Knabe, 1972).

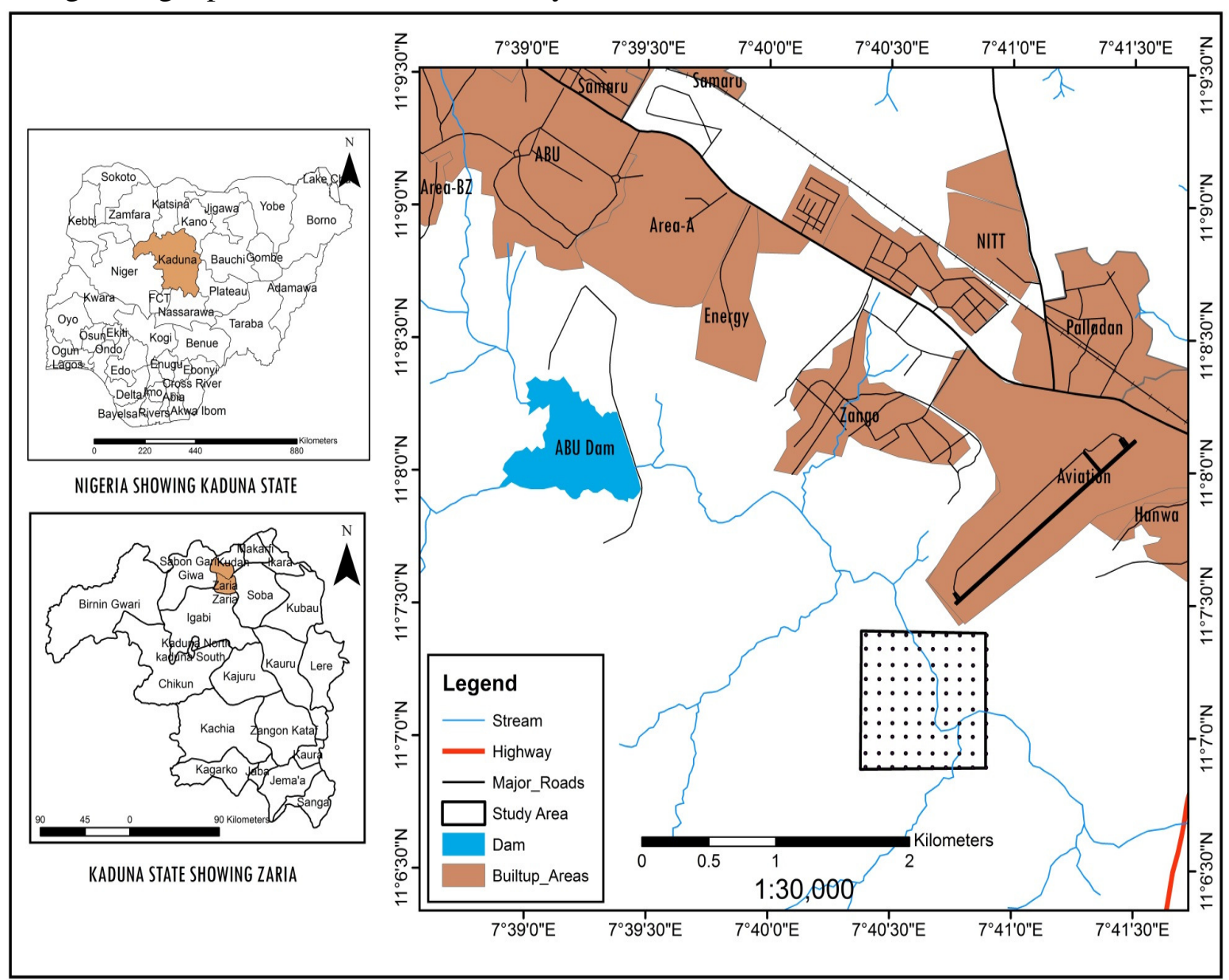

Figure 1: Zaria Showing the Study Area

Source: Adapted From Quick Bird 2011 Imagery 
Geologically the area lies within the high plains of Northern Nigeria characterize by landforms which consist of inselbergs and pediment landscape overlying the basement complex which are nearly level to gentle undulating plains (Yakubu, 2004).

\section{Sample Collection}

A detailed soil survey using rigid-grid method $(100 \mathrm{~m} \times 100 \mathrm{~m})$ on a 70 ha land was carried out. Soil units were mapped out and two modal profile pits were dug and examined according to Soil Survey Staff (2010) procedure. Bulk soil samples were collected from various genetic horizons identified within the profile pit of each soil mapping units. The samples were air dried, sieved with a $2 \mathrm{~mm}$ sieve and analysed in the laboratory.

\section{Sample Analyses}

Particle size distribution was determined by the hydrometer method (Gee and Bauder, 1979). Bulk density was determined using the core sampler (Blake and Hartge, 1986).Soil $\mathrm{pH}$ was measured in water and $0.01 \mathrm{M} \mathrm{CaCl} 2(1: 2.5 \mathrm{w} / \mathrm{v})$ using glass electrode $\mathrm{pH}$ meter (Agbenin, 1995). Organic carbon was determined by the dichromate wet oxidation method of Walkley and Black (Nelson and Sommers, 1982). The cation exchange capacity (CEC) was determined using the ammonium acetate method (Agbenin, 1995). Base saturation was calculated as the sum of total exchangeable bases divided by cation exchange capacity
( $\mathrm{NH}_{4} \mathrm{OAc}$ ) (Agbenin, 1995). Available $\mathrm{P}$ was determined using Bray 1 method (IITA, 1979). Total $\mathrm{N}$ was determined by the kjeldahl method (Bremmer and Malvaney1982). Exchangeable bases (calcium, magnesium, potassium and sodium) in the soil were determined using the ammonium acetate extract from the CEC determination. Sodium and $\mathrm{K}$ was determined using flame photometer while $\mathrm{Ca}$ and $\mathrm{Mg}$ were determined using atomic absorption spectrometer.

Statistical Analysis

Analyses Of Variance (ANOVA) were used to ascertain whether or not there were significant differences in the physical and chemical properties of the three mapping units.

\section{Land Evaluation}

The land suitability evaluation for maize was carried out using the FAO method (FAO, 1983) (Table 1). Key environmental factors considered in the evaluation were climate (annual rainfall, temperature), topography (slope) and soils. The identified soil units were placed in suitability classes by matching their characteristics with requirements of the test crop. The most limiting characteristic dictate overall suitability for each soil unit using limiting condition procedure. The suitability of each factor for respective soil unit was classified as highly suitable (S1), moderately suitable (S2), marginally suitable (S3) or not suitable (N). 
Table 1 Factor Suitability Rating for Maize

\begin{tabular}{lllll}
\hline $\begin{array}{l}\text { Land Characteristic / } \\
\text { diagonistic factor }\end{array}$ & $\begin{array}{l}\text { Highly suitable } \\
(\mathrm{S} 1)\end{array}$ & $\begin{array}{l}\text { Moderately } \\
\text { Suitable (S2) }\end{array}$ & $\begin{array}{l}\text { Marginal } \\
\text { Suitable (S3) }\end{array}$ & $\begin{array}{l}\text { Not Suitable } \\
(\mathrm{N})\end{array}$ \\
\hline Climate & & & & \\
Rainfall $(\mathrm{mm})$ & $>800$ & $700-800$ & $600-700$ & $<600$ \\
$\begin{array}{l}\text { Temperature }\left({ }^{\circ} \mathrm{C}\right) \\
\text { Land/soil physical property }\end{array}$ & $24-30$ & $20-24,30-32$ & $15-20,32-35$ & $<15,>35$ \\
Slope $(\%)$ & $0-2$ & $4-8$ & $8-16$ & $>16$ \\
Soil depth $(\mathrm{cm})$ & $>120$ & $75-120$ & $30-75$ & $<30$ \\
Soil Texture & $\mathrm{CL}, \mathrm{L}$ & $\mathrm{SL}, \mathrm{LS}$ & $\mathrm{LCS}$ & $\mathrm{CS}$ \\
Volume of coarse fragment & $<5$ & $5-25$ & $46-70$ & $>70$ \\
Drainage & Well & Moderately & Imperfect & very poor \\
Nutrient availability (top soil) & & & & \\
pH & $6-6.5$ & $5.5-6.0,6.5-7$ & $5.0-5.5,7.0-8.2$ & $<5.0->8.2$ \\
Organic Carbon $\left(\mathrm{gkg}^{-1}\right)$ & $>2.0$ & $1.0-0.2$ & $0.5-1.0$ & $<0.5$ \\
Total Nitrogen $\left(\mathrm{gkg}^{-1}\right)$ & $0.8-0.4$ & $0.4-0.2$ & $<0.2$ & Any \\
Available P $\left(\mathrm{mgkg}^{-1}\right)$ & $>40$ & $10-40$ & $3-10$ & $<3$ \\
Exchangeable K $\left(\mathrm{mgkg}^{-1}\right)$ & $0.3-0.5$ & 0.2 & $0.1-0.2$ & $<0.1$ \\
CEC $\left(\mathrm{cmol}\left(++\mathrm{kg}^{-1}\right)\right.$ & $>25$ & $13-25$ & $6-12$ & $<6$ \\
Base Saturation $(\%)$ & $>80$ & $40-80$ & $20-40$ & $<20$ \\
$\begin{array}{l}\text { Salinity and Sodicity } \\
\text { Salinity EC }(\mathrm{ds} / \mathrm{m})\end{array}$ & & & & \\
Sodicity ESP $(\%)$ & $<1$ & $1-2$ & $2-4$ & $>4$ \\
\hline A & $<10$ & $10-15$ & $>15$ & - \\
\hline
\end{tabular}

Adopted from FAO (1983); Oluwatosin (2005).

Key: $\mathrm{CL}=$ clay loam, $\mathrm{L}=$ loam, $\mathrm{SL}=$ sandy loam, $\mathrm{LS}=$ loam sand, $\mathrm{LCS}=$ loam clay sand, $\mathrm{CS}=$ clay sand

\section{Result and Discussion \\ Soil Characteristics of the Study Area}

Three soil mapping units were delineated and denoted GBI, GBII and GBIII based on soil colour, texture, drainage and depth. Land qualities of the soils units are shown in Table 2. The soils were rated using the critical limits recommended by (Malgwi, 2007). Soil mapping unit GBI was deep, well drained, dark yellowish brown in colour, loam to sandy clay loam in texture, well developed profile and covers an area of 12.3ha. Soil mapping unit GBII was shallow to very deep, well to imperfectly drained, strong brown to light gray brown, loam to sandy clay loam in texture, weakly developed profile characterized by deep gully erosion and covers an area of 38.8ha. Soil mapping unit GBIII was deep, imperfectly drained, yellowish brown to gray brown, loam to silt loam in texture, well developed profile and covers an area of 18.9ha.

Sand dominated the particle-size fraction of soils. The soil reaction was slightly acidic to neutral (6.1-7.3). This result was in conformity with earlier report by Lawal et al. (2012) and these values are within the $\mathrm{pH}$ requirement for most arable crops (Brady and Weil, 1999). Generally, organic carbon (O.C), available phosphorus (Ap) and total nitrogen (TN) was rated low according to Malgwi (2007) soil rating. CEC value (8.4 -12.6) were rated medium to high based on the ratings of Adepetu et al. (1979) who reported CEC values of $<6,6-12$ and $>12 \mathrm{cmol}$ (+) $\mathrm{kg}^{-1}$ as low, medium and high respectively. 
Soil Suitability Evaluation for Rain-Fed Maize Production.................JIMOH et al.

Table 2: Land Qualities/Characteristics of Gabari District

\begin{tabular}{|c|c|c|c|}
\hline \multirow{2}{*}{$\begin{array}{l}\text { Land Characteristic / Diagonistic Factor } \\
\text { Climate }\end{array}$} & \multicolumn{3}{|c|}{ Soil Mapping Units } \\
\hline & GBI & GBII & GBIII \\
\hline Mean Annual rainfall (mm) & 1004 & 1004 & 1004 \\
\hline Temperature $\left({ }^{\circ} \mathrm{C}\right)$ & 26 & 26 & 26 \\
\hline \multicolumn{4}{|l|}{ Land/soil physical property } \\
\hline Slope $(\%)^{1}$ & $0-2$ & $0-4$ to $0-16$ & $0-2$ \\
\hline Soil Depth $(\mathrm{cm})$ & $>140$ & $50-170$ & $>170$ \\
\hline Soil Texture Class & $\mathrm{L}, \mathrm{SL} / \mathrm{SCL}$ & L/CL,SCL & $\mathrm{L} / \mathrm{SiL}$ \\
\hline \multicolumn{4}{|l|}{ Volume of coarse fragment } \\
\hline Drainage & Well drained & $\begin{array}{l}\text { Well to Imperfect } \\
\text { drained }\end{array}$ & $\begin{array}{l}\text { Imperfectly } \\
\text { drained }\end{array}$ \\
\hline \multicolumn{4}{|l|}{ Nutrient availability (top soil) } \\
\hline $\mathrm{pH}\left(\mathrm{H}_{2} \mathrm{O}\right)$ & 6.6 & 6.65 & 6.6 \\
\hline Organic Carbon $\left(\mathrm{gkg}^{-1}\right)$ & 8.1 & 4.6 & 4.7 \\
\hline Total Nitrogen $\left(\mathrm{gkg}^{-1}\right)$ & 0.18 & 0.14 & 0.14 \\
\hline Available $\mathrm{P}\left(\mathrm{mgkg}^{-1}\right)$ & 3.07 & 2.63 & 3.59 \\
\hline Exchangeable K $\left(\mathrm{mgkg}^{-1}\right)$ & 0.16 & 0.14 & 0.13 \\
\hline $\mathrm{CEC}\left(\mathrm{cmol}(+) \mathrm{kg}^{-1}\right)$ & 8.4 & 11.6 & 12.65 \\
\hline Base Saturation (\%) & 60.48 & 53.28 & 44.48 \\
\hline \multicolumn{4}{|l|}{ Salinity and Sodicity } \\
\hline Salinity EC (ds/m) & 0.07 & 0.05 & 0.03 \\
\hline Sodicity ESP (\%) & 4.89 & 3.66 & 3.98 \\
\hline
\end{tabular}

$\mathrm{CL}=$ Clay loam, $\mathrm{L}=$ loam, $\mathrm{SL}=$ sandy loam, $\mathrm{LS}=$ loamy sand, $\mathrm{LCM}=$ loamy coarse sand,

$\mathrm{CS}=$ coarse sand

The medium level of the CEC might be a reflection of the intensity of weathering that produced the soils. Base saturation $\left(\mathrm{NH}_{4} \mathrm{OAc}\right)$ of surface soils were rated medium $(50-80 \%)$ in all the units, similar result was reported by (Atofarati et al., 2012). The FAO (1999) reported that soils with base saturation of $>50 \%$ are regarded as fertile soils while soils with less $<50 \%$ were regarded as not fertile soils. The soils are generally fertile. The EC and ESP values were generally lower than $4 \mathrm{ds} / \mathrm{m}$ and $15 \%$ respectively considered defining the soils as been saline and sodic.

For improved crop yields on short term, mineral fertilizers could be recommended as a stop-gap to promote higher crop yields. However, for a longterm sustainable crop production, soil fertility restoration measures affordable to farmers should be adopted. Among these measures are the uses of organic manure to improve the soils physical and chemical constraints. Alternatively green maturing practices (e.g. groundnut and other nonfood legumes) should be introduced as a very economic measure for soil fertility improvement and regeneration. This measure according to Yadav et al. (2001) increases crop yields by $20-30 \%$, improves soil nitrogen and phosphorus by $25 \%$, restores natural fertility and stimulates plant growth. Generally, there were no significant differences $(\mathrm{P}>0.05)$ in the physical and chemical properties of the soils within the three mapping units (Table $3)$. 
Table: 3 Result of Analysis of Variation within the three mapping units

\begin{tabular}{lllllll}
\hline Source & & & & & F critical \\
Variation & SS & Df & MS & F & P-value & value \\
\hline Between Groups & 1.102471 & 2 & 0.551235 & 0.001622 & 0.99838 & 3.178799 \\
Within Groups & 17336.47 & 51 & 339.9308 & & & \\
Total & 17337.58 & 53 & & & & \\
\hline
\end{tabular}

Qualitative Land Suitability Classification for Maize Production

A summary of land qualities/land characteristics of the study area is shown in Table 2 and the assessment ratings resulting from matching of land qualities and the requirements for maize was presented in Table 1 using the FAO (1983) suitability ratings. Soil mapping units GBI and GBIII have effective soil depth $>100$ $\mathrm{cm}$ and thus were rated highly suitable (S1) while mapping unit GBII with depth of $50-170$ was rated marginally suitable (S3) for maize.

Mean annual rainfall and temperature was considered highly suitable (S1). On the basis of soil texture, soil mapping units GBI, GBII, GBIII which were loam, overlaying loam, sandy clay loam, clay loam was highly suitable (S1) for maize. Fasina and Adeyanju (2006) reported that slope of $<3 \%$ may favour mechanical operation. The slope of $<2 \%$ made soil mapping units GBI and GBIII soil units highly suitable (S1) while soil mapping unit GBII with slope of 4-16 was currently Not suitable (N1). The entire soil mapping units were perfectly drained, hence rated highly suitable (S1) except soil mapping unit GBIII which was imperfectly drained as such classified marginally suitable (S3) due to its aquic condition which may constitute major limitation for the growing of maize. Drainage is required for maize which was known to be non-tolerant to water-logging conditions. Regarding soil reaction $(\mathrm{pH})$, soil mapping units GBI, GBII and GBIII were highly suitable (S1). Considering nutrient retention (CEC) soil mapping units GBI and GBII were marginally suitable (S3) while soil mapping unit GBIII was moderately suitable (S2). Furthermore, with regard to organic carbon (OC) and total nitrogen (TN) all the soil mapping units were marginally suitable (S3), for available $\mathrm{P}$ content, soil mapping units GBI and GBIII were marginally suitable (S3) while soil mapping unit GBII was not suitable $(\mathrm{N})$. Soil mapping units GBI, GBII and GBIII were marginally suitable (S3) with regard to exchangeable $\mathrm{K}$. All the soil mapping units were moderately suitable (S2) with regarding to percent base saturation (BS). All the soil mapping units were highly suitable (S1) with regards to salinity and sodicity (Table 4). 
Table 4: Matching Landuse Requirement with Land Quality for Maize

\begin{tabular}{lllll}
\hline $\begin{array}{llll}\text { Land Characteristic / Diagonistic } \\
\text { Factor }\end{array}$ & & $\begin{array}{l}\text { Soil } \\
\text { GBI }\end{array}$ & $\begin{array}{l}\text { Mapping } \\
\text { GBII }\end{array}$ & $\begin{array}{l}\text { Units } \\
\text { GBIII }\end{array}$ \\
\hline $\begin{array}{llll}\text { Climate } \\
\text { Rainfall }\end{array}$ & $(\mathrm{mm})$ & $\mathrm{S} 1$ & $\mathrm{~S} 1$ & $\mathrm{~S} 1$ \\
$\begin{array}{l}\text { Temperature } \\
\text { Land/soil physical property } \\
\text { slope (s) }\end{array}$ & $\left({ }^{\circ} \mathrm{C}\right)$ & $\mathrm{S} 1$ & $\mathrm{~S} 1$ & $\mathrm{~S} 1$ \\
Soil depth & $(\%)$ & $\mathrm{S} 1$ & $\mathrm{~N}$ & $\mathrm{~S} 1$ \\
Soil Texture & $(\mathrm{cm})$ & $\mathrm{S} 1$ & $\mathrm{~S} 3$ & $\mathrm{~S} 1$ \\
Volume of coarse fragment & $(\%)$ & $\mathrm{S} 1$ & $\mathrm{~S} 1$ & $\mathrm{~S} 1$ \\
Drainage (d) & $(\%)$ & $\mathrm{S} 1$ & $\mathrm{~S} 1$ & $\mathrm{~S} 1$ \\
Nutrient availability (top soil) & $(\mathrm{f})$ & $\mathrm{S} 1$ & $\mathrm{~S} 1$ & $\mathrm{~S} 3$ \\
pH & $\left(\mathrm{H}_{2} \mathrm{O}\right)$ & $\mathrm{S} 1$ & $\mathrm{~S} 1$ & $\mathrm{~S} 1$ \\
Organic Carbon $(\mathrm{m})$ & $\left(\mathrm{gkg}^{-1}\right)$ & $\mathrm{S} 3$ & $\mathrm{~S} 3$ & $\mathrm{~S} 3$ \\
Total Nitrogen $(\mathrm{t})$ & $\left(\mathrm{gkg}^{-1}\right)$ & $\mathrm{S} 3$ & $\mathrm{~S} 3$ & $\mathrm{~S} 3$ \\
Available P(p) & $\left(\mathrm{mgkg}^{-1}\right)$ & $\mathrm{S} 3$ & $\mathrm{~N}$ & $\mathrm{~S} 3$ \\
Exchangeable K & $\left(\mathrm{mgkg}^{-1}\right)$ & $\mathrm{S} 3$ & $\mathrm{~S} 3$ & $\mathrm{~S} 3$ \\
CEC (c) & $\left(\mathrm{cmolkg}^{-1}\right)$ & $\mathrm{S} 3$ & $\mathrm{~S} 3$ & $\mathrm{~S} 2$ \\
Base Saturation $(\mathrm{n})$ & $(\%)$ & $\mathrm{S} 2$ & $\mathrm{~S} 2$ & $\mathrm{~S} 2$ \\
Salinity and Sodicity & & & & \\
Salinity EC (e) & $(\mathrm{ds} / \mathrm{m})$ & $\mathrm{S} 1$ & $\mathrm{~S} 1$ & $\mathrm{~S} 1$ \\
Sodicity ESP & $(\%)$ & $\mathrm{S} 1$ & $\mathrm{~S} 1$ & $\mathrm{~S} 1$ \\
\hline Overall Suitability & & $\mathrm{S} 3 \mathrm{f}-1$ & $\mathrm{~N} 1 \mathrm{tf}-2$ & $\mathrm{~S} 3 \mathrm{df}-3$ \\
\hline f & & & & \\
\hline
\end{tabular}

$\mathrm{f}=$ fertility, $\mathrm{t}=$ slope

Soil mapping units GBI and GBIII were marginally suitable (S3) while GBII was currently not suitable (N1) for maize production due to low organic carbon, available phosphorus and total nitrogen; soil mapping units GBIII and GBII have in addition drainage and steep slope limitation respectively. This confirm results of Oluwatosin (2005) who reported that low fertility, erosion hazard and drainage are factors limiting productivity of savannah soil for crop production. Ogunkule (1993) also reported that soil fertility is the major limitation to the suitability of Nigeria soils.

The overall Suitability of the Gabari soils for maize were classified as follows: Mapping units GBI and GBIII were classified into the order S (suitable), class S3 (marginally suitable), and subclass $f$ and d (fertility and drainage), while units were f-1 (fertility) and f-3 (fertility and drainage) respectively. Mapping units GBII was classified in the order $\mathrm{N}$ (not suitable), class N1 (currently not suitable) and subclass $\mathrm{f}$ and $\mathrm{t}$ (fertility and slope), while unit was f-2 (fertility and slope). Soil mapping unit GBI was classified as S3f-1, which represent deficiency of organic carbon, total nitrogen and available $\mathrm{p}$, GBII as N1f-2 which represent deficiency of organic carbon, total nitrogen, available $\mathrm{p}$ and slope limitation and GBIII as S3f-3 which represent deficiency of organic carbon, total nitrogen, available $\mathrm{p}$ and drainage limitation for maize production at the unit level of classification (figure 2).

\section{Conclusion}

Generally, the entire soil mapping units assessed were rated medium based on 
nutrient status, but in term of suitability for maize they were marginally to currently not suitable due to low organic carbon, total nitrogen and available phosphorus and slope. However, for optimum performance and upgrade of the suitability of the area to moderate/highly suitable, recommended rate of NPK-fertilizer, manure application and management practices that will encourage the return of plants/crop residues into these soils to improve the soils physical and chemical constraints. Soil mapping unit GBII with very steep slope limitation will require terracing plough to reduce high rate of erosion while mapping unit GBIII will require field drainage.

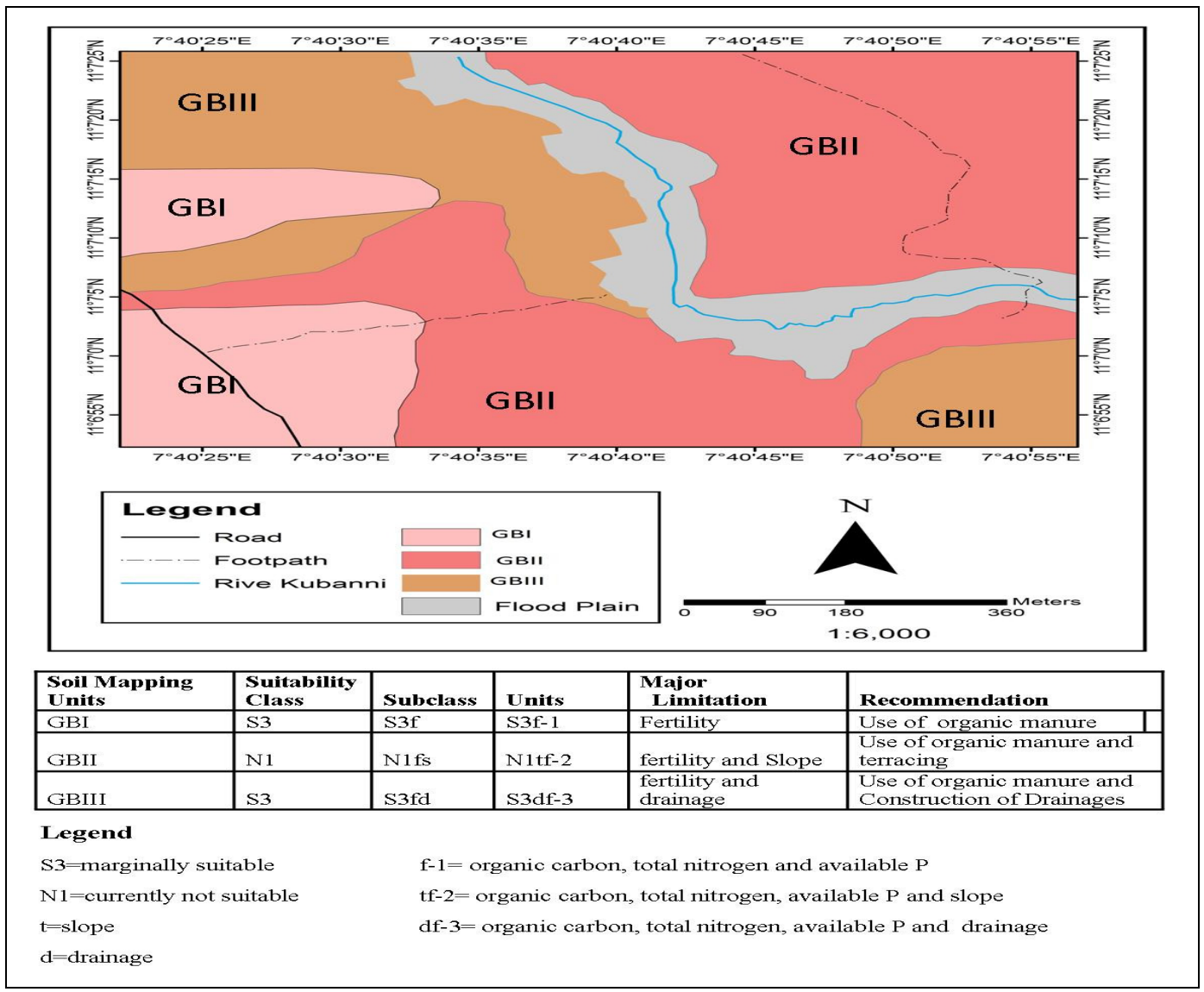

Figure 2: Suitability map of Gabari District

\section{References}

Abdulkadir, A. (1998). Soil type and their management in the southern lake area, Nigeria. Proceedings of the 12th National Irrigation and drainage Seminar on Irrigation and Sustainable Agriculture. IAR, ABU, Zaria, Nigeria. 14th-16th April, 1998. Pp334- 348.
Abdulkadir, A. (1986). Land Evaluation for Irrigation in Bauchi State. Unpublished Ph.D. Thesis Bayero University Kano. pp 187

Adepetu, J.A., Aduagi, E.A. and Alofa, C.A. (1979). A preliminary of fertility status of some soils in Ondo state under traditional cultivation. Ife Journal of Agriculture 134:149. 
Soil Suitability Evaluation for Rain-Fed Maize Production.................JIMOH et al.

Agbenin, J.O. (1995). Laboratory Manual for Soil and Plant Analysis.Department of Soil Science, Ahmadu Bello University Zaria, Kaduna State.

Atofarati, S.O., Ewulo, B.S., Ojeniyi S.O. (2012). Characterization and classification of soils on two toposequence at Ile-Oluji, Ondo State, Nigeria. International Journal of Agri. Science, 2(7): 642-650.

Akande, S.O. (1994). Comparative Cost and Return in Maize Production in Nigeria. Nigeria Institute for Social and Economic Research (NISER) individual Research Project Report, Ibadan: NISER.

Badmus, M.A. and Ariyo, O.S. (2011). Forecasting Cultivated Areas and Production of Maize in Nigerian using ARIMA Model. Asian Journal of Agricultural Sciences 3(3): 171176 ,

Brady, N.C. and Weil, R.R. (1999). The Nature and Properties of Soils. $12^{\text {th }}$ ed. Prentice Hall, upper Saddle River, New York. 881pp.

Bremmer, J.M. and Mulvaney, C.S. (1982). Nitrogen - Total. p. 595-624. In Page A., L., Miller, R., H. and Keeney, D., R., (eds.) Methods of Soil Analysis. Part 2. Chemical and Microbiological Properties.2nd ed. Agron. Monogr. 9. ASA and SSSA, Madison, WI.

FAO (1976). A frame work for land evaluation, Soil Bulletin, vol 32, FAO, Rome.

FAO (1983). Guidelines: Land Evaluation for Rain-fed Agriculture. Soil Bulletin No 52, Food and Agriculture Organization, Rome, 237 pp.

FAO (1995). Guidelines; Land Evaluation for rainfall agriculture. Soil
Resources Management and Conservation Service, Land and Water Development Division Rome.FAO Soil Bulletin.52 pp237.

FAO (1999).World Reference Base for Soil Resources. World Soil Resources Rep. vol. 84. Food and Agricultural Organisation of the UN, Rome, Italy, $161 p$.

Fasina, A.S. and Adeyanju, A. (2007). Comparison of three Land Evaluation Systems in Evaluating the Predictive Value of some selected soils in AdoEkiti, Southwest Nigeria. J. soil sci. 17:113-119.

Gee, G.W. and Bauder, J.N. (1979). Particle Size Analysis By Hydrometric Method; A Simplified Method For Routine Textural Analysis And Sensitivity Test Of Mineral Parameters, Soil Scienc Society, American Journal, 43: 10041007.

Hussaini, G.M. (2011). Land Suitability Evaluation for Some Selected Land Use Type in the Institute for Agricultural Research Farm, Zaria, Nigeria. Unpublished M.Sc. Thesis. Department of Soil Science, ABU, Zaria.

IITA (1979). Selected Methods for Soil and Plant Analysis. $2^{\text {nd }}$ edn., International Institute of Tropical Agriculture, Ibadan, Oyo State, Nigeria, Pages: 70.

Jafarzadeh, A.A. and Abbasi, G. (2006). Qualitative land suitability evaluation for the growth of onion, potato, maize, and alfalfa on soils of the Khalatpushan research station. Biologia,61(19): 349-352.

Kowal, D. and Knabe, D.J. (1972). An Agroclimatological Atlas of the 
Northern State of Nigeria. Ahmadu Bello Univ. press, Zaria, Nigeria.

Lawal, B.A., Ojanuga, A.G., Noma, S.S., Adeboye, M.K.A., Dikko, A.U. and Singh, A. (2012). Suitability Evaluation of Soils of Lower River Oshin Floodplain, Kwara State, Nigeria for Rain-Fed Arable Crop Cultivation. Nigerian Journal of Soil and Environmental Research, 10:71 78.

Malgwi, W.B. (2007). Soil Survey: Soil Analytical Data Interpretation for Land Management. Paper presented at Training Workshop in Soil Survey and Land Evaluation Methodology for Federal Department of Agriculture and Land Resource Staff in Kaduna.

Nelson, M.J. and Sommers, L.E. (1982). Total Carbon, Organic Carbon and Organic Matter. In: Page, L.A., Miller, R.H. and Keeney, D.R. (eds), Methods of Soil Analysis, pp. 539579. Part 2. Chemical and Microbiological Methods $\left(2^{\text {nd }} e d\right)$. American Society of Agronomy. Madison, W.I

Njar, G.N., Iwara, A.I., Egbe, M., Offiong, R.A. and Essoka, P.A. (2012). An Evaluation of Soil Suitability for Maize Production In Obiaruku Community In Nigeria. British
Journal of Advance Academic Research, 1(1): 16-27.

Ojo, S.O. (2003). Productivity and technical efficiency of poultry egg production in Nigeria, Intl. J. Poul. Sci., 2(6): 459-464.

Oluwatosin, G.A. (2005). Land Suitability Assessment in Continental Grits of Northwestern Nigeria for Rainfed Crop Production. West African Journal of Applied Ecology, 7:5367.

Van Diepen, C.A., Van Keulen, H., Wolf, J. and Berkhout, J. A.A. (1991). Land Evaluation: From Intuition to Quantification. In: Advances in Soil Science (B. A. Stewart) (ed). Springer, New York, pp. 139-204.

The World Bank (1998). Human Development Report. The World Bank, Washington D C.

Yadav, A.K., Chaudhuri, S.R. and Motsara, M.R. (2001). Recent Advances in Biofertilizer Technology. Society for Promotion and Utilization of Resources and Technology. 526.

Yakubu, S. (2004). Assessment of soil changes under different land uses in Zaria area, Northern Nigeria. Unpublished M.Sc., thesis Department of Geography, ABU Zaria. 